\title{
WHAT MAKES A GREAT WALL ARISE?: EXPERIENCE OF SOCIAL STUDIES TEACHER IN CREATING INSTRUCTIONAL MEDIA BASED ON ICT
}

\author{
Muhammad Khoiron* \\ State University of Surabaya, Indonesia
}

\begin{abstract}
The challenge of teachers in the era of the industrial revolution 4.0 is inevitable, the teachers must keep abreast of continued technological developments, including in the making of instructional media. Not infrequently they face quite serious problems when making ICT-based instructional media. This paper aims to understand (1) What causes problems in making ICT-based instructional media appear; and (2) How problems in creating ICT-based instructional media can arise. The method used is qualitative with a phenomenological approach. Data collected from results of in-depth interviews and participatory observation. The informants in this study consist of all social studies teachers in one of the best junior high schools in Malang, Indonesia. The collected data were analyzed using the stages of Transcription, Horizonalization, and Cluster of Meaning. The study results show that problems in making ICT-based instructional media arise due to: (1) Lack of habituation, (2) the age of the teacher (3) no assistance, (4) generation, (5) too many additional assignments from school, and (6) limited of time. And how the great wall of problems arises because of internal and external sides. From the internal side is the attitude that is built up in the social studies teacher, while from the external side is the attitude that is built up within the school and government policy. Between the two things (internal and external) there is no mutually supporting harmonization. The conclusions of this study show that harmonization between the internal and external sides is needed to reduce policy errors or misconduct which in turn cause problems in making ICT-based instructional media.
\end{abstract}

Keywords: Social Studies, Instructional Media, Phenomenology, ICT

\section{Introduction}

Human life is very dynamic. Changes can occur at any time with or without our knowledge. Following the 3.0 industrial revolution, now humans have faced revolution renewal to the 4.0 era. In this era, the joints of human life experienced many changes not only in the field of communication (Faheem et al., 2018; Marcon et al., 2017; Tunison, 1920), but also in the field of information (Aldwairi \& Alwahedi, 2018; Zhuang, Chen, \& Li, 2017), and no exception in the field of education (Lase, 2019; Puncreobutr, 2016; Shahroom \& Hussin, 2018). The format of learning in this era experienced many significant changes. One of them is the emergence of the Internet of Things, Virtual Reality, Augmented Reality, and Cloud technology that can be used in the world of education (Mourtzis, Vlachou, Dimitrakopoulos, \& Zogopoulos, 2018). In this condition, it can be said that humans have entered the era of digitalization in the world of education, or better known as the era of education 4.0.

The era of education 4.0 directs people to care about the demands of the age that requires humans to develop dynamically according to their environment. It can also be said as education that responds to the industrial revolution 4.0 where humans occupy a position parallel to technology in terms of discovering new possibilities (Aziz, 2018). The development of technology presents a big challenge in the world of education (Benešová \& Tupa, 2017). If it is not implemented, humans who cannot keep up with these developments may be replaced by technology itself. So what is the current practice of integrating information communication technology (ICT) in education? Many studies show that optimal engagement of ICT can help the learning process (Jimoyiannis \& 
Komis, 2007; Kumar, 2009; Livingstone, 2012; Noor-Ul-Amin, 2013; Salehi \& Salehi, 2012). Some things that can be improved by engaging ICT into learning process are learning motivation, learning outcomes, and student participation..

The number of studies that show improvement in some aspects of learning when engaging ICT does not mean that in practice all schools and all teachers in the world can apply it optimally. In fact, studies have been found about the importance of increasing teacher competence in the engagement of ICT (Rivalina, 2014; Tondeur et al., 2017). There are some teachers who face big problems in engaging ICT in the world of education. Because after all, teacher competence plays an important role in the engagement of ICT (Vitanova, AtanasovaPachemska, Iliev, \& Pachemska, 2015). Such conditions are also found in the Brawijaya Smart School (BSS) Malang Middle School, one of private schools in Indonesia. Based on the results of observations, the authors found that teachers at the school also still needed increased competence in the engagement of ICT. There are still some teachers who face major problems in it. Especially the Social Sciences (IPS) teacher in making ICTbased instructional media.

Based on current conditions and also some previous studies that have been presented. In this study, the focus will be on discussing:

(1) What causes problems in making ICT-based instructional media appear; and

(2) How problems in creating ICT-based instructional media can arise.

Studies like this are not novel. However, what distinguishes this study from previous studies is this study's point of view. This study tries to understand meaning based on the perspective of the owner of the experience that will be elaborated in the research method.

\section{Research Methods}

This study applies a qualitative method with the Phenomenology approach. The informants who participated were all social studies teachers in SMP BSS. They consist of 3 teachers, with initial code YPA, EL, and S. Data collection in Phenomenology is collected by in-depth interviews and participatory observation (Creswell, 2007). To maintain the naturalness of the data that emerged, in-depth interviews were conducted in an unstructured way. We walks along the flow of the conversation during in-depth interviews. As it is said that the study of phenomenology seeks to understand meaning based on the perspective of the owner of experience (Gill, 2014). In the study of phenomenology, its inventors believe that by holding back all forms of dogma, suspicion, a priori, and apotheosis to theory can lead to a refresher of philosophy or point of view (Moran, 2016).

The analysis technique in this study consists of the stages of transcription, horizonalization, and cluster of meaning (Hasbiansyah, 2005). At the transcription stage the author fully describes the phenomena experienced by the informant. All recorded interviews with in-depth research informants were transcribed into written language. At the horizonalization phase, the writer inventory important statements that are relevant to the topic. At this stage, the writer must be patient to delay the assessment. The element of subjectivity of the author may not interfere in the effort to detail the important points of the results of the interview. Furthermore, in the cluster of meaning stage, the writer classifies the statements into themes or units of meaning, as well as setting aside overlapping or repetitive statements. Steps in this stage: (a) Textural description: The researcher writes what is experienced, namely a description of what the individual experiences; (b) Structural description: The writer writes how the phenomenon is experienced by individuals. After that the authors construct a comprehensive description of the meaning and essence of experience. 


\section{Results and Discussion}

\section{Search of Meaning}

We write this section based on what the informants have experienced. As a principle in the phenomenological approach, restrain all forms of dogma, suspicion, a priori, and theoretical deification in order to obtain a refresher on the philosophy or point of view that the informant conveyed. So data collected from transcription results are processed in the Horizonalization stage. Because not all results in transcription can be used and relevant to the research topic. After that the results of the Horizonalization stage enter the Cluster of Meaning section. This section will be presented in a statement table from the informants. The statement here is divided into two parts. Namely a statement that states textural description (things experienced by BSS Middle School Social Sciences teacher), and statements stating structural descriptions (in the form of opinions, assessments, feelings, expectations of Social Sciences BSS Middle School teachers about the phenomena they experience). After the statement can be distinguished between textural and structural, the writer groups the statement into themes or units of meaning, as well as setting aside repeated or overlapping statements. The researcher also looks for all possible meanings based on the researchers own reflection, in the form of opinions, judgments, feelings, expectations of research subjects about the phenomena they experience.

\section{Statement from the Informant}

\section{First Informant}

The first informant was a 44 years old. Her informant code is "YPA". She is married and has two children. The following is a description of her. For details of informant statement can be seen in table 1 .

Table 1. Textural and Structural Description from "YPA"

\begin{tabular}{ll}
\hline Textural Description & Structural Description \\
\hline Practice often & The level is more difficult \\
Endless & I always forget it \\
Make it incidental & Lack of practice \\
Sometimes when teaching & I try not to continue working at home \\
Making media that is not too complicated & The time is very urgent so I make powerpoint \\
Not too many formulas & Age factor \\
Doing homework & Habituation \\
In a hurry & Time is limited \\
Already taught & We choose the simplest way \\
Nobody asked & Young people are more updated \\
Attend 1-2-day workshop & Like carving on water \\
The education authorities asks to be resolved & Too fast \\
immediately & The question was all busy \\
All teachers here have additional assignments & The task that is given by the institution to us is that we \\
When I was in college I didn't have a laptop & must go on \\
Used or not there are no demands & We cannot compete with young people \\
Outdated & \\
Now everything is ICT-based & \\
\end{tabular}




\section{Second Informant}

The second informant is a 50-year-old woman. Her Informant code is "EL". Has a family and has one child. The following is a description of the second informant. For details of informant statement can be seen in table 2.

Table 2. Textural and Structural Description from " $E L$ ”"

\begin{tabular}{ll}
\hline Textural Description & Structural Description \\
\hline Not only about teaching & Technology is increasingly sophisticated \\
Had attended practice, at that time could but & We need special expertise to make media \\
now forgot & I can only PowerPoint \\
It is hard to manage time & Temands are too many \\
There is no accompaniment media for learning & Need a companion \\
Ask for help & Accompanied until it can \\
The young ones & I am still having trouble \\
When I was in college there wasn't & Especially my age \\
There is no computer & The time is very little \\
Dealing with our troubled students & It is difficult because I am married \\
New student admission activities & We as homeroom teachers \\
Student guidance & Actually intensive if it is possible \\
Go home until five o'clock & If only one semester is certainly lack \\
School policy & Once a week maybe make it together \\
Once it is not complete & \\
Only one day & \\
\end{tabular}

\section{Third Informant}

The third informant is a 62-year-old male. His initial is "S". He is married and has two children. He became social studies teacher over 5 years. For details of informant statement can be seen in table 3 .

Table 3. Textural and Structural Description from " $S$ "

\begin{tabular}{ll}
\hline Textural Description & Structural Description \\
\hline I have never attended practice & There is little possibility of difficulties in making ICT- \\
Still learning again to friends who can & based instructional media \\
The old media & We ask from friends who can \\
Still using sheets on paper & I am the the old base teacher \\
Take free time & I teach since there is no ICT yet \\
Sometimes at school & Now the media is very sophisticated \\
Sometimes at home & Now the change in ICT has been so great \\
Additional out of service hours & What should I do to manage time? \\
& We make this ICT-based instructional media training
\end{tabular}




\section{Emerging Meaning Units}

Some units of meaning that arise from the results of data processing taken from the informants show several units of meaning. Social studies teachers at BSS Middle School face problems in making instructional media because of the following things; (1) Lack of habituation; (2) The age of the teacher; (3) Lack of assistance; (4) Generational Difference; (5) Too many additional tasks from school; and (6) Limited time. The details can be seen in the following table:

Table 4. Emerging Meaning Units from Informants

\begin{tabular}{ll}
\hline Meaning Units & Description of Meaning \\
\hline Lack of habituation & $\begin{array}{l}\text { Training in making ICT-based instructional media is often } \\
\text { done but at the end is forgotten due to lack of habituation }\end{array}$ \\
\hline Teacher's age & $\begin{array}{l}\text { Learning to make ICT-based instructional media at an old age } \\
\text { is less than optimal }\end{array}$ \\
\hline Absence of Assistance & $\begin{array}{l}\text { Learning ICT-based instructional media requires an assistance } \\
\text { that is always there to be consulted }\end{array}$ \\
\hline Generational Difference & $\begin{array}{l}\text { When they were in college, they were not taught about ICT- } \\
\text { based instructional media as it is today }\end{array}$ \\
\hline $\begin{array}{l}\text { Too Many Additional Assignments from } \\
\text { School }\end{array}$ & $\begin{array}{l}\text { In addition to teach, teachers also get many additional } \\
\text { assignments from schools such as administrative files. }\end{array}$ \\
\hline Limited of time & $\begin{array}{l}\text { To learn how ICT media-based learning is, they need a long } \\
\text { time, but many tasks must be done. }\end{array}$ \\
\hline
\end{tabular}

Description of the Problems of Social Sciences Teachers in Creating ICT-Based Instructional media.

\section{Lack of Habituation}

The level of complexity of the operation of ICT-based instructional media software varies. Some have low, medium or high complexity. But this is very relative, depending on the capabilities possessed by each individual. When a teacher is accustomed to using PowerPoint ICT-based instructional media software in his/her daily life, the teacher will say he/she has no difficulty in operating it. But the story will be different when the teacher tries to operate a new instructional media software that is not accustomed to being used, what happen is the teacher has difficulty in operating it.

As one of the efforts so that social studies teachers in SMP BSS can operate ICT-based instructional media software is by attending training or workshops. The school has held such training or workshops several times. Instructional media that are trained are flipbook and flash based instructional media. After attending the Social Studies teacher training at BSS Middle School they were only able to remember for a short time, after that they forgot how to operate the instructional media. This is due to lack of habituation because it is preoccupied with other activities.

Because preoccupied with other activities in the end the knowledge of the operation of flash instructional media obtained from training or workshops was forgotten. Regarding the results of the training or workshop, the school itself did not provide follow-up. After the workshop or training activities are finished, the Social Sciences teacher at BSS Middle School is not required to use it in learning. Teachers are given the freedom to use media as what in their learning. So that after teachers are preoccupied with other activities, what happens they forget the knowledge gained from workshops or instructional media training, due to lack of habituation. 


\section{Teacher's Age}

The three Social Sciences teachers at BSS Middle School are no longer young teachers. Already married and have children. At the time of the study data the YPA informants were 39 years old, EL 45 years old, and S 58 years old. They are not in young age anymore. Because of this age, social studies teachers at BSS Middle School have limitations in understanding technology. In the end they were faced with problems when they wanted to make ICT-based instructional media.

The young age makes it difficult for informants to understand ICT-based instructional media. so informants inevitably make ICT-based instructional media choose which is not too complicated and not too much formula. When they were no longer young, social studies teachers at BSS Middle School had difficulty learning. Studying in old age when likened to carving on water, will quickly disappear. Learning ICT-based instructional media at a young age will be difficult, because of busyness and memory that is less than the maximum. So that the science of operating ICT-based instructional media that is obtained is quickly forgotten.

\section{Absence of Assistance}

Activities to improve the ability of Social Sciences teachers of SMP BSS in making ICT-based instructional media have indeed been carried out. One of them is through training and workshops based on ICT-based instructional media. However, according to the information, the short implementation of training and workshop media is less than optimal. They still need others to ask questions.

A new problem finally arises, when the BSS Middle School Social Sciences teacher needs someone else to ask questions but that person is not there. Nothing is meant does not mean that in BSS Middle School there are no teachers who are able to master ICT-based instructional media. Actually they are there, but do not have the free time to guide social studies teachers who want to learn about ICT-based instructional media.

Informants need assistance from other people who are more knowledgeable about instructional media. However, because people who are more knowledgeable about instructional media are also busy with their work, finally the informant does not have mentors who can be asked and directed to create ICT-based instructional media. The existence of people who are more knowledgeable in ICT-based instructional media is very much needed by Social Sciences teachers in SMP BSS. Because with the assistance of Social Sciences BSS Middle School teacher can ask questions and get directions at any time when facing difficulties in making ICT-based instructional media.

\section{Generational Difference}

All social studies teachers in SMP BSS are the generation that was born where information and communication technology did not use computers as at the time of this writing. When they went to college to get a college degree there was also no adequate computer facilities as at present. So they do not get lecture material about ICT-based instructional media, but rather instructional media that are still traditional in nature.

The limited technology in the lecture period caused Social Sciences teachers of BSS Middle School to learn ICT-based instructional media themselves. There is no ICT-based instructional media taught during the lecture period. Now the development of technology is very different. They even felt the difference when they started their careers as educators. At that time there was no technology that supported using ICT-based instructional media. There is no LCD, there is an Over Head Projector (OHP). 


\section{Too Many Additional Assignments from School}

The task of the teacher at SMP BSS is not just to focus on teaching. But many other tasks given by the school. Likewise with the Social Sciences teachers at BSS Middle School, they have many additional tasks that must be completed as well. The assignments given by schools affect their daily activities, including in making ICT-based instructional media.

The number of additional tasks given by the school makes one of the causes of the emergence of teacher problems in making ICT-based instructional media. The task held by the informant is not just to teach students. Each teacher has an additional assignment. Sometimes because of the additional assignment it makes the informant forget if he had to make instructional media. Tasks that have become responsibilities must be completed by informants, such tasks as being the homeroom teacher. When becoming a homeroom teacher the informant had to deal with problem children. In addition there is also the task of Admission of New Students (PPDB), workshops, seminars, as well as correcting questions about students' tests.

The number of additional tasks held by social science teachers at SMP BSS makes them absorbed in their activities. Late in doing assignments as homeroom teacher, late in workshops, in seminar activities, late in correcting student test questions, and late in PPDB assignments as seen in the following picture:

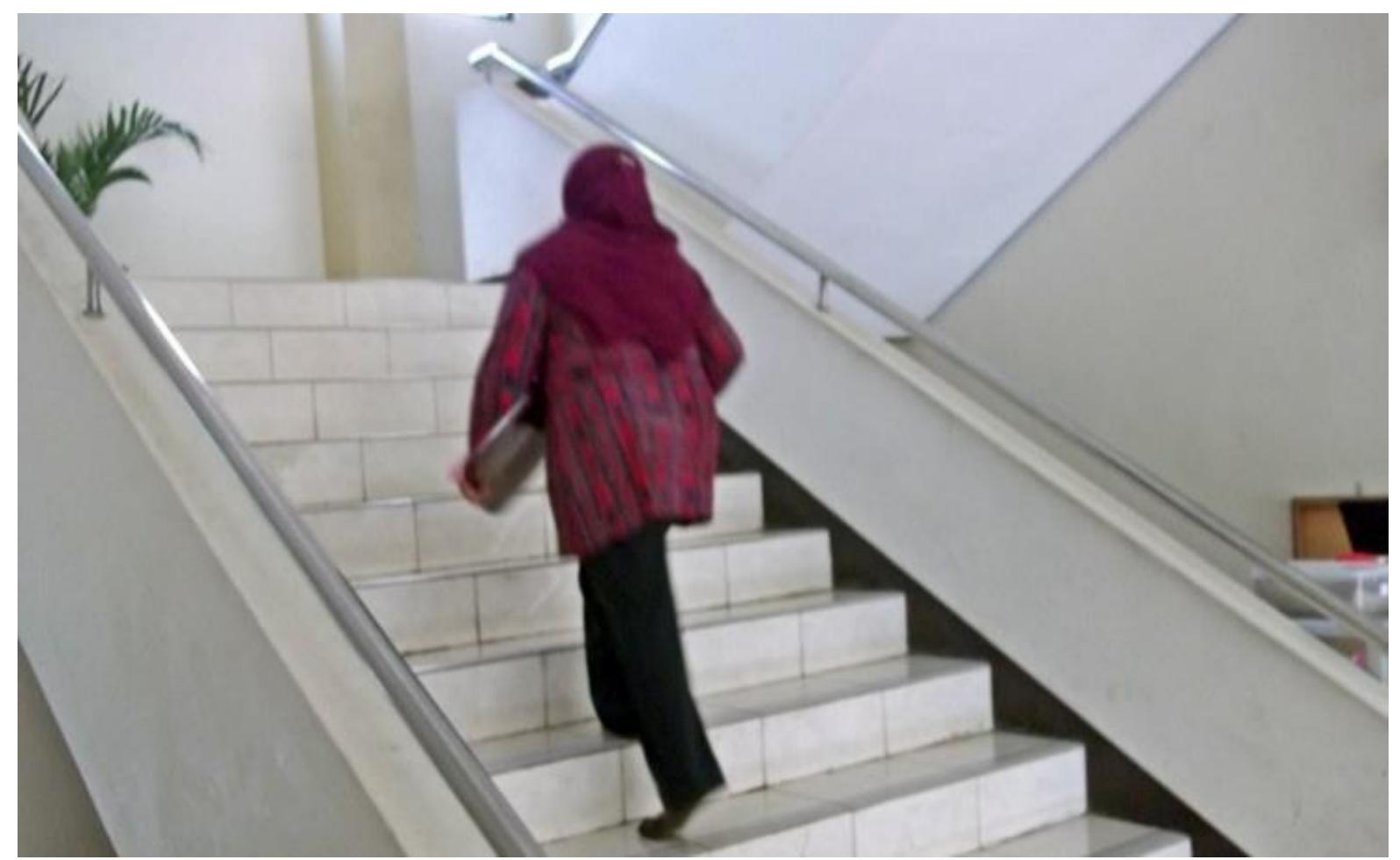

Figure 1. EL Informant Climbs the Stairs While Carrying a Tray When Becoming a New Student Admission Committee (Researcher's personal documentation).

In Figure 1, it can be seen that the EL informant is dissolving in his daily life when he is a PPDB committee. Mrs. Esti was seen climbing the stairs and holding the tray for PPDB purposes. In addition to teaching Ms. Esti also received additional assignments, one of which was to become a PPDB committee. 


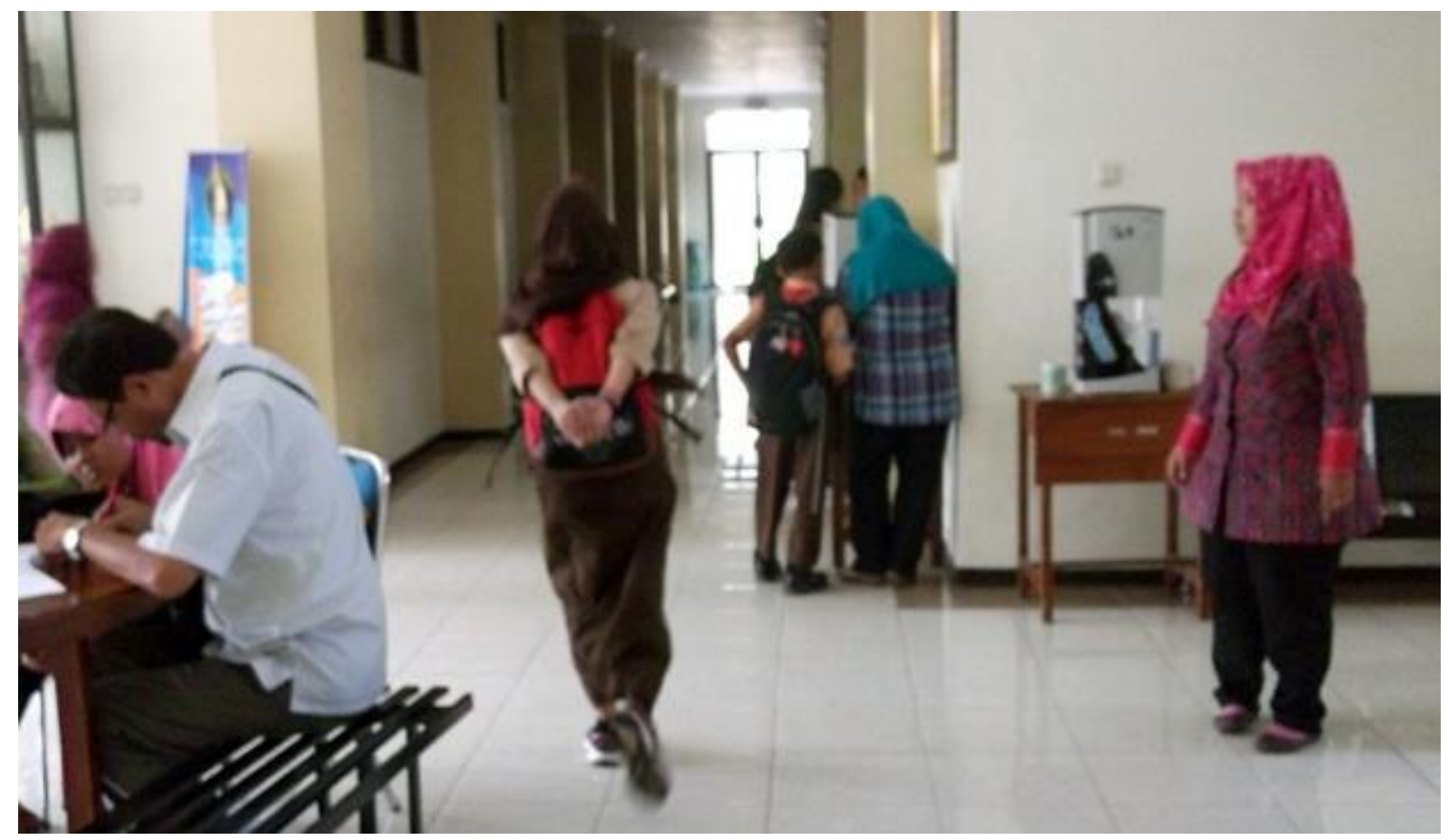

Figure 2. Ms. Yuli Hooded in Pink Standing To Welcome PPDB Test Participants (Researcher's personal documentation)

In Figure 2, YPA Informant (right-hand pink veil) is dissolving in his daily life when he is a PPDB committee. In picture 2 the YPA informant stands up to welcome PPDB participants. Because the teacher's assignment at SMP BSS besides teaching also gets an additional assignment. One of them is to become a PPDB committee. Additional tasks often make YPA dissolved in its activities.

\section{Limited time}

Learning and making ICT-based instructional media requires a relatively long time. While the time owned by the informant is very limited. The lack of time finally led informants to choose to use ICT-based instructional media software that was as easy and simple as PowerPoint. Meanwhile, other instructional media software obtained from training or workshop is not implemented.

The lack of time for learning and habituation affects the difficulty of teachers in understanding technology, especially learning technology. Because to learn ICT based instructional media basically does require considerable time. If time is lacking for learning what happens is the difficulty in understanding learning technology.

\section{Conclusion}

The experience of social studies teachers at SMP BSS in making ICT-based instructional media has its own meaning. Based on the information from the informants in this study, we can understand that what causes the emergence of a big wall (problem) appears in making ICT-based instructional media not only because of the internal side or self of the teacher. But it also has to do with the external side, or from the institution where they are teachers. Both school and related government institutions.

As if from an internal perspective we can understand the causes of the emergence of problems are age, lack of habituation, lack of time, or because they are from different generations. But it all indirectly exists because of 
external factors as well. Such as the absence of assistance from institutions and the number of additional tasks given.

The great wall in creating ICT-based instructional media arises because there has not been harmonization between the internal and external sides. In other words, what is given by the informant is not necessarily what is needed by the institution, so also what is given by the institution is not necessarily what the informant needs. For example, the teacher gives learning that is less optimal because there is no time to prepare the learning because of the many assignments given by the school. Or institutions provide ICT-based instructional media workshop in one or two days, which in the end the teachers forget and do not use them. Even though what they need is not workshop, but assistance. For this reason, it is necessary to harmonize between the internal and external sides.

\section{Acknowledgements}

I am very grateful to LPDP (Indonesian Education Fund Management Agency endowment fund for education) for funding my education, so that I can participate in this conference. I also don't forget to say thank you to Dr. Harmanto, Mpd., Prof. Dr. Aminuddin Kasdi, MS, and Agnia Rizqi Wardani, S.Pd. which has helped in my studies.

\section{References}

Aldwairi, M., \& Alwahedi, A. (2018). Detecting fake news in social media networks. Procedia Computer Science, 141, 215222. https://doi.org/10.1016/j.procs.2018.10.171

Aziz, A. (2018). Education 4.0 Made Simple: Ideas For Teaching. International Journal of Education and Literacy Studies, 6(3), 92. Retrieved from https://journals.aiac.org.au/index.php/IJELS/article/view/4616

Benešová, A., \& Tupa, J. (2017). Requirements for Education and Qualification of People in Industry 4.0. Procedia Manufacturing, 11(June), 2195-2202. https://doi.org/10.1016/j.promfg.2017.07.366

Creswell, J. W. (2007). Qualitative Inquiry and Research Design: Choosing Among Five Approaches. In Book (Second Edi). https://doi.org/10.1016/j.aenj.2008.02.005

Faheem, M., Shah, S. B. H., Butt, R. A., Raza, B., Anwar, M., Ashraf, M. W., ... Gungor, V. C. (2018). Smart grid communication and information technologies in the perspective of Industry 4.0: Opportunities and challenges. Computer Science Review, 30, 1-30. https://doi.org/10.1016/j.cosrev.2018.08.001

Gill, M. J. (2014). The Possibilities of Phenomenology for Organizational Research. Organizational Research Methods, 17(2), 118-137. https://doi.org/10.1177/1094428113518348

Hasbiansyah, O. (2005). Pendekatan Fenomenologi; Pengantar Praktik Penelitian dalam Ilmu Sosial. (56), 163-180.

Jimoyiannis, A., \& Komis, V. (2007). Examining teachers' beliefs about ICT in education: Implications of a teacher preparation programme. Teacher Development, 11(2), 149-173. https://doi.org/10.1080/13664530701414779

Kumar, R. (2009). Convergence of ICT and education. World Academy of Science, Engineering and Technology, 40(July), $556-559$.

Lase, D. (2019). Education and Industrial Revolution 4.0 Delipiter. https://doi.org/10.24114/jh.v10i1

Livingstone, S. (2012). Critical reflections on the benefits of ICT in education. Oxford Review of Education, 38(1), 9-24. https://doi.org/10.1080/03054985.2011.577938

Marcon, P., Zezulka, F., Vesely, I., Szabo, Z., Roubal, Z., Sajdl, O., ... Dohnal, P. (2017). Communication technology for industry 4.0. Progress in Electromagnetics Research Symposium, 1694-1697. https://doi.org/10.1109/PIERS.2017.8262021

Moran, D. (2016). INTRODUCTION TO PHENOMENOLOGY. https://doi.org/10.1108/S0749-742320160000019022

Mourtzis, D., Vlachou, E., Dimitrakopoulos, G., \& Zogopoulos, V. (2018). Cyber- Physical Systems and Education 4.0 -The Teaching Factory 4.0 Concept. Procedia Manufacturing, 23(2017), 129-134. https://doi.org/10.1016/j.promfg.2018.04.005

Noor-Ul-Amin, S. (2013). An Effective use of ICT for Education and Learning by Drawing on Worldwide Knowledge , Research, and Experience : ICT as a Change Agent for Education. Department Of Education University of Kashmir, 1(1), 1-13. https://doi.org/6th August 2016

Puncreobutr, V. (2016). Education 4.0: New Challenge of Learning. Humanitarian and Socio-Economic Sciences, 2(2), 92 97. Retrieved from http://scopuseu.com/scopus/index.php/hum-se-sc/article/view/188

Rivalina, R. (2014). Kompetensi Teknologi Informasi Dan Komunikasi Guru Dalam Peningkatan Kualitas Pembelajaran. Jurnal Teknodik, 18(2), 165-176. 
Salehi, H., \& Salehi, Z. (2012). Challenges for Using ICT in Education: Teachers' Insights. International Journal of EEducation, e-Business, e-Management and e-Learning, 2(1), 40-43.

Shahroom, A. A., \& Hussin, N. (2018). Industrial Revolution 4.0 and Education. International Journal of Academic Research in Business and Social Sciences, 8(9), 314-319. https://doi.org/10.6007/ijarbss/v8-i9/4593

Tondeur, J., Aesaert, K., Pynoo, B., van Braak, J., Fraeyman, N., \& Erstad, O. (2017). Developing a validated instrument to measure preservice teachers' ICT competencies: Meeting the demands of the 21st century. British Journal of Educational Technology, 48(2), 462-472. https://doi.org/10.1111/bjet.12380

Tunison, B. R. (1920). The future of industrial alcohols. Industrial and Engineering Chemistry, 12(4), 370-376. https://doi.org/10.1021/ie50124a022

Vitanova, V., Atanasova-Pachemska, T., Iliev, D., \& Pachemska, S. (2015). Factors Affecting the Development of ICT Competencies of Teachers in Primary Schools. Procedia - Social and Behavioral Sciences, 191, 1087-1094. https://doi.org/10.1016/j.sbspro.2015.04.344

Zhuang, Y. B., Chen, J. J., \& Li, Z. hong. (2017). Modeling the cooperative and competitive contagions in online social networks. Physica A: Statistical Mechanics and Its Applications, 484, 141-151. https://doi.org/10.1016/j.physa.2017.04.129 